(Uniwersytet Jagielloński, Kraków,

e-mail: p.palka@uj.edu.pl)

ORCID: 0000-0001-6412-414X

\title{
ALTERNACJA LOKATYWNA W WYBRANYCH LEKSYKALNYCH BAZACH DANYCH
}

\section{WPROWADZENIE}

Głównym przedmiotem zainteresowania w niniejszym artykule jest omówienie tego, czy i w jaki sposób zjawisko alternacji lokatywnej w ujęciu Beth Levin [1993; zob. też Levin, Rappaport Hovav 2005] jest uwzględniane i opisywane w wybranych polsko-, angielsko- i rosyjskojęzycznych naukowych ${ }^{1}$ opracowaniach leksykograficznych. Celem analizy jest również próba odpowiedzi na pytanie, czy alternujace ze soba konstrukcje składniowe wiążą się $z$ jakąś zmianą w przekazywanej treści, a ściślej w sposobie obrazowania danej sytuacji. B. Levin, omawiając różnego typu alternacje w języku angielskim, używa ogólnego terminu argument alternation lub diathesis alternation, wyjaśniając to zjawisko następująco:

(...) native speakers can make extremely subtle judgments concerning the occurence of verbs with a range of possible combinations of arguments and adjuncts in various syntactic expressions. For instance, speakers of English know which diathesis alternation - alternations in the expressions of arguments, sometimes accompanied by changes of meaning - verbs may participate in [Levin 1993, 2; zob. też Levin, Rappaport Hovav 2005, 17]. ${ }^{2}$

${ }^{1}$ Określenie to odnosi się do typologii słowników Piotra Żmigrodzkiego, który wyróżnia naukowe i popularne dzieła leksykograficzne. Te pierwsze adresowane są do specjalistów, to publikacje $z$ dziedziny określonych działów językoznawczych, te drugie zaś skierowane są do wszystkich odbiorców, a zwłaszcza tych bez wykształcenia filologicznego [Żmigrodzki 2005, 239-240].

2 „(...) rodzimi użytkownicy języka w odmiennych konstrukcjach składniowych potrafią wyrażać w sposób bardzo subtelny pewne różnice związane $z$ szeregiem możliwych kombinacji argumentów i modyfikatorów występujących z danymi czasownikami. Na przykład użytkownicy języka angielskiego wiedza, w którym typie diatezy - alternacji w sposobie wyrażania argumentów, czasem powiazanej z pewnymi zmianami semantycznymi - dane czasowniki moga uczestniczyč" [tłum. PP]. Zjawiskiem alternacji, w tym alternacji lokatywnej, w różnych językach zajmowali się także m.in.: Anderson 1971; Goldberg 1995, 
Jednym $z$ rodzajów regularnej wariancji składniowej w uzewnętrznianiu argumentów jest alternacja lokatywna, zaliczana w klasyfikacji B. Levin do nadrzędnej grupy alternacji wymagających określonych argumentów w ramach grupy werbalnej [Levin 1993, 45-79, zob. Alternations Involving Argument Within the VP]. Dotyczy ona, jak podaje badaczka, przynajmniej dwóch sposobów (np. „a. Henry cleared dishes from the table (...) b. Henry cleared the table of dishes"; ${ }^{3}$ Levin 1993, 52] wyrażania w zdaniu argumentów przyjmujących cechy: 1. 'obiekt zmieniający lokalizację' (locatum argument) i 2. 'miejsce' (location argument) [zob. Levin 1993, 50; za: Clark, Clark 1979]. Zasada jest taka, że argumenty te moga być realizowane wymiennie na poziomie zdania w formie frazy nominalnej, pełniacej wówczas funkcję dopełnienia bliższego. Alternacja lokatywna jest charakterystyczna zwłaszcza dla tych czasowników, które opisują sytuacje związane $z$ umieszczaniem czegoś na jakiejś powierzchni lub $z$ wkładaniem czegoś do pojemnika albo $z$ usuwaniem substancji lub jakichś rzeczy $z$ danej powierzchni bądź pojemnika. Zachodzi więc ona m.in. dla następujących klas: czasowniki spryskiwania / ładowania (Spray / Load Verbs, np. brush, crowd, loud, pack, spray, wrap), czasowniki oczyszczania (Clear Verbs, np. clear, clean, drain, empty), czasowniki wycierania (Wipe Verbs) z możliwymi podklasami: podklasa sposobu (Manner Subclass, np. bail, dust, polish, scrub, shave, wipe, sweep) i podklasa narzędzia (Instrument Subclass, np. brush, filter, iron, mop, comb, towel) oraz czasowniki tłoczenia się (Swarm Verbs, np. abound, bustle, crawl, creep, swarm) [Levin 1993, 50-55].

\section{ALTERNACJA LOKATYWNA W JĘZYKU POLSKIM - MOŻLIWE WARIANCJE SKEADNIOWE}

Alternacji lokatywnej podlegają także czasowniki w języku polskim, choć zagadnienie to wymaga szczegółowych i głębszych badań. W niniejszym artykule ograniczymy się jedynie do tych czasowników, które w swej semantyce zawierają odniesienie do usuwania czegoś $z$ danej powierzchni, a sa to m.in. takie leksemy jak: czyścić, golić, ogolić, obetrzeć, obmieść, otrzepać, plewić, skubać, skrobać, sprzatać, strzyc, trzepać, wyczesać, wyczyścić, wyplewić, wyskrobać, wytrzeć, wytrzepać, zamiatać, zgolić. Za przypadek alternacji lokatywnej należy uznać między innymi takie przekształcenia składniowe ${ }^{4}$ jak:

106-107, 175-179; Goldberg 2006, 34-38; Brinkmann 1997; Laffut 1998; zob. też pełny wykaz literatury: Levin 1993, 49-50.

3 „a. Henry posprzątał naczynia ze stołu (...) b. Henry posprzatatał stół $z$ naczyń" [tłum. PP].

4 Wszystkie podawane w artykule przykłady przekształceń sa wyekscerpowane $z$ NKJP lub tekstów internetowych. Zapisywane sa one w postaci oryginalnej bądź nieco sparafrazowanej czy skróconej. 
1a. Dozorca zamiata śmieci z ulicy. $\rightarrow 1$ b. Dozorca zamiata ulice ze śmieci.

2a. Dzieci plewia chwasty z trawnika. $\rightarrow 2$ b. Dzieci plewia trawnik z chwastów.

3a. Sasiadka trzepie kurz $z$ dywanu. $\rightarrow$ 3b. Sasiadka trzepie dywan $z$ kurzu.

4a. Góral strzyże wełne $z$ owcy. $\rightarrow$ 4b. Góral strzyże owcę $z$ wełny.

5a. Tata otrzepał błoto $z$ butów. $\rightarrow 5$ b. Tata otrzepał buty $z$ błota.

6a. Brat skrobat lód $z$ szyby. $\rightarrow$ 6b. Brat skrobat szybę $z$ lodu.

7a. Ciotka goli włosy z nóg. $\rightarrow 7 \mathrm{~b}$. Ciotka goli nogi z włosów.

8a. Matka wytarka pot $z$ twarzy. $\rightarrow$ 8b. Matka wytarka twarz $z$ potu.

9a. Gospodyni skubała pierze z gessi. $\rightarrow$ 9b. Gospodyni skubała gęś z pierza.

10a. Dzieci sprzataja śmieci z lasu. $\rightarrow 10 \mathrm{~b}$. Dzieci sprzataja las ze śmieci.

O zjawisku alternacji, $z$ odwołaniem do ujęcia B. Levin, pisała Elżbieta Hajnicz [2011, 103-129], definiujacc je jako regularna

wariantywność w syntaktycznym uzewnętrznieniu argumentów czasownikowych. Zasada jest taka, że dwa zdania tworza alternacje, jeśli ich znaczenie jest identyczne (bądź przynajmniej ostatecznie zbliżone) lub też znaczenie jednego jest uszczegółowieniem znaczenia drugiego (zawieranie) [Hajnicz 2011, 104].

Badaczka dookreśla jednak omawiane zjawisko, biorąc pod uwagę specyfikę języka polskiego, i stwierdza, że poszczególne typy alternacji można sklasyfikować, wykorzystując zarówno kryterium syntaktyczne, jak i semantyczne. Według pierwszego kryterium alternacje dziela się na te, które zachowuja stronę i na te, w których zachodzi transformacja zwrotna. Z kolei pod kątem semantycznym można wyróżnić alternacje: zachowujące (przybliżone) znaczenie wypowiedzenia (w obu schematach realizowane sa wszystkie argumenty) oraz te, w których jedna realizacja jest uszczegółowieniem znaczenia drugiej realizacji [Hajnicz 2011, 105]. W wypadku podanych powyżej konstrukcji typu 1a. Dozorca zamiata śmieci z ulicy $\rightarrow$ 1b. Dozorca zamiata ulice ze śmieci mamy zatem do czynienia $z$ alternacja krzyżowa, w której zachowana jest strona i która podlega regularnemu przekształceniu składniowemu następujących schematów: $\mathrm{NP}^{1}{ }_{\text {Nom }} \mathrm{V} \mathrm{NP}^{2}{ }_{\text {Acc }}$ $\mathrm{XP}_{\text {abl }}^{3}\left(\operatorname{PrepNP}_{z, \mathrm{Gen}}^{3}\right)^{5} \rightarrow \mathrm{NP}^{1}{ }_{\mathrm{Nom}} \mathrm{V} \mathrm{NP}^{2}{ }_{\mathrm{Acc}} \operatorname{PrepNP}_{z, \mathrm{Gen}}{ }^{6}{ }^{6}$ Następuje tu krzyżowa zamiana dopełnienia bliższego i dopełnienia dalszego / okolicznika, wiażąca się, zdaniem E. Hajnicz, z tym, że znaczenia obu zdań alternujących ze sobą są zgodne semantycznie [2011, 110-111]. Według badaczki do uszczegółowienia znaczenia pierwszego wypowiedzenia dochodzi $z$ kolei w wypadku:

1. alternacji zaniku, która zachowuje stronę i polega na pominięciu argumentu w drugim schemacie, np. Dozorca zamiata śmieci z ulicy. $\rightarrow$

5 Podana w schemacie fraza ablatywna została użyta tu celowo, choć skupiamy się w niniejszym artykule jedynie na jej realizacji w formie konkretnej frazy przyimkowo-nominalnej, która jest: PrepNP ${ }_{z, G e n}$. Zdajemy sobie jednak sprawę $z$ możliwych innych użyć (zależnych od wymagań składniowo-semantycznych) danego czasownika typu: wytrzeć [coś] spod stotu, wytrzepać [coś] zza kotnierza, sprzątnąć [coś] spomiędzy szafek itp.

6 Zapis skrótów w opisie składniowym przyjmujemy częściowo za: Przepiórkowski i in. 2014. 
Dozorca zamiata śmieci; Dozorca zamiata ulice ze śmieci. $\rightarrow$ Dozorca zamiata ulice, oraz

2. alternacji przesunięcia - zachowującej stronę i zachodzącej dla różnych schematów składniowych (tu: $\mathrm{NP}^{1}{ }_{\text {Nom }} \mathrm{V} \mathrm{NP}^{2}{ }_{\text {Acc }} \mathrm{XP}^{3}{ }_{\text {abl }}\left(\operatorname{PrepNP}_{\text {na,Loc) }}{ }^{2}\right.$ $\rightarrow \mathrm{NP}^{1}{ }_{\mathrm{Nom}} \mathrm{V} \mathrm{NP}_{\text {Acc }}^{2}$ PrepNP$^{3}$,Gen $)$, w ramach których dochodzi do przesunięcia jednego argumentu $z$ pominięciem drugiego - realizowanego na poziomie zdania w formie frazy przyimkowej, np. Dozorca zamiata okruszki na podłodze $\rightarrow$ Dozorca zamiata podłogę.

Wydaje się jednak, że możliwość faktycznego potwierdzenia zgodności lub niezgodności czy uszczegółowienia bądź rozszerzenia znaczenia zdań realizujących alternacje lokatywną typu krzyżowego, jak i zaniku czy przesunięcia, wymaga bliższego przyjrzenia się charakterystyce semantycznej argumentów implikowanych przez omawiane predykaty oraz ich układowi.

\section{HIERARCHIA I CHARAKTERYSTYKA SEMANTYCZNA AKTANTÓW}

Biorąc pod uwagę użycia czasowników typu: Matka zamiatała miotła śmieci $z$ podłogi, mamy do czynienia $z$ sytuacja czteroaktantowa, która, używając tradycyjnej terminologii Charlesa J. Fillmore'a dotyczaccej przypadków głębokich ${ }^{7}$ [1968, 24-25; 1971], obejmuje:

1. agensa (będącego człowiekiem, który inicjuje wydarzenia opisywane przez czasownik): Matka zamiatała miotła śmieci z podłogi;

2. narzędzie (będące przedmiotem powiązanym przyczynowo $z$ akcją wyrażoną przez dany czasownik): Matka zamiatała miotta śmieci $z$ podŁogi;

3. obiekt (będacy przedmiotem działania wyrażonego przez czasownik; tu locatum argument 'obiekt zmieniajacy lokalizację') [zob. Levin 1993, 50]: Matka zamiatała miotła śmieci $z$ podłogi;

4. źródło (miejsce, $z$ którego coś bierze kierunek, będace punktem początkowym czynności; 8 tu location argument) [zob. Levin 1993, 50]: Matka zamiatała miotła śmieci z podtogi.

Także w sytuacji, określanej przez dany czasownik, a ujętej w realizacjach typu Matka zamiatała miotła podłogę ze śmieci, aktantom należy przypisać podobne role w nieco innym układzie:

7 Na temat rozwoju koncepcji i zestawów ról semantycznych zob. m.in. Fillmore 1971, 1977; Apresjan 1980; Levin, Rappaport Hovav 2005; zob. też Linde-Usiekniewicz 2010.

$8 \mathrm{~W}$ wypadku tylko niektórych $\mathrm{z}$ omawianych tu czasowników, np. zamiatać, wyróżnia się w strukturze składniowo-semantycznej miejsce jeszcze dla jednego argumentu, którym jest cel 'punkt końcowy jakiejś akcji, przemieszczania', np. W kacie krypty leży sterta ludzkich kości. To szczątki zakonników. Ktoś z UCK zamiótt je do kata (...) [NKJP]. 
1. agensa (por. jak wyżej): Matka zamiatała miotła podłoge ze śmieci;

2. narzędzie (por. jak wyżej): Matka zamiatała miotta podłoge ze śmieci; 3. obiekt - źródło ${ }^{9}$ (tu location argument - miejsce, $z$ którego coś jest usuwane i które jest zarazem obiektem czynności, na który się działa $z$ powodu tego, że jego powierzchnia jest pokryta jakąś drobną materia czy substancją (możliwa do usunięcia)): Matka zamiatała miotła podtoge ze śmieci;

4. obiekt (por. jak wyżej, locatum argument): Matka zamiatała miotka podłoge ze śmieci.

Podkreślmy, że ostatni $z$ wymienionych aktantów (obiekt - location argument), który choć jest elementem struktury głębokiej, to powierzchniowo, jak wykazuje analiza uzusu w NKJP, zwykle nie jest wyrażany. Świadcza o tym liczne w korpusie zdania $z$ użyciem kolokacji takich jak: zamiatać alejke, bruk, chodnik, deptak, droge, dziedziniec, izbee, jezdnie, klatke, korytarz, nawierzchnie, park, peron, podłoge, podwórko, podwórze, pokój, schody, ścieżkę, ulicę..., bez dookreślenia w tekście wprost, co $z$ owych miejsc konkretnie się zamiata, np.:

Stróżka wyszła jak co dzień z wiklinowa miotła zamiatać podwórko [NKJP]. (...) opięty białym pasem $z$ koalicyjka, zamiatat trotuar ogromna miotka [NKJP]. Jestem jednym $z$ setek turystów, po których skwapliwy dozorca sprzata zamiatając posadzke ostra miotła [NKJP].

W związku z tym takiemu argumentowi, wykorzystując „filmowa” terminologię Jeleny W. Paduczewej, można przypisać rangę komunikatywna - poza kadrem, gdyż, jak ujmuje to badaczka, z perspektywy komunikacyjnej nie jest on widoczny ani na planie pierwszym (zajmowanym przez uczestników centralnych), ani drugim (wypełnionym przez uczestników peryferyjnych) [Paduczewa 1998,5$].{ }^{10} \mathrm{~W}$ analizowanych re-

9 Badacze różnia się w opisie tej pozycji argumentowej w ramach omawianego wariantu alternacji lokatywnej. W bazie czasowników rosyjskich Leksykograf pisze się o miejscu - pacjensie [zob. hasło: 1.2. мести умицу - Kustowa, Paduczewa, Rozina i in. 2009-2010]. We FrameNecie jest Source [zob. np. czasownik clear w ramie Removing: https:/ / framenet.icsi.berkeley.edu/fndrupal/]. $\mathrm{Z}$ kolei w słowniku Walenty podaje się Theme $e^{\text {Source }}$ [zob. np. hasło wytrzepać: http://walenty.ipipan.waw.pl/]. Wszystkie te koncepcje zostana omówione w dalszej części pracy.

10 J.W. Paduczewa wyjaśnia to następująco: „(...) в ситуации разцичается передний план и периферия (соответственно, бывают центральные и периферийные участники; им соответствуют центральные и периферийные компоненты толкования). (...) Мы апемлируем к понятию д и а т е з ы из [Мельчук, Холодович 1970], но определяем диатезу несколько иначе - как набор участников ситуации с их коммуникативными рангами: Субъект, Объект, Периферия, За кадром, см. об этом подробно [Падучева 1997]. (Дело в том, что Субъект и Объект, будучи синтаксическими категориями, имеют, однако, непосредственную коммуникативную значимость; термин 
alizacjach alternacji lokatywnej mamy więc do czynienia $z$ przesunięciem diatetycznym polegającym tu na zmiennym (a raczej odwrotnym czy wzajemnie wymiennym) układzie aktantów (raz obiektem jest 'drobna materia', raz 'obiekt mający powierzchnię', na którą można działać, usuwając coś $z$ niej). Wymianie podlega także ranga komunikatywna uczestników sytuacji [zob. Paduczewa 1998; Kustowa, Paduczewa, Rozina, Xasina i in. 2009]:

1. agens -2 . obiekt 'drobna materia' - 3. narzędzie

- 4. źródło 'powierzchnia obiektu'

1. centrum -2 . centrum -3 . peryferie -4 . peryferie

1. agens - 2. obiekt-źródło 'powierzchnia obiektu' - 3. narzędzie - 4. obiekt 'drobna materia'

1. centrum -2 . centrum -3 . peryferie -4 . poza kadrem

\section{ALTERNACJA LOKATYWNA W POLSKIM SEOWNIKU WALENCYJNYM - WALENTY}

Przyjrzyjmy się teraz, jak interesujące nas czasowniki realizujące alternację lokatywna, a zwłaszcza implikowane przez nie argumenty: locatum argument i location argument (podlegajace wymianie $\mathrm{w}$ tej alternacji), opisywane sa w opracowywanym w IJP PAN najnowszym polskim słowniku walencyjnym - Walenty [zob. http:/ / walenty.ipipan.waw. $\mathrm{pl} /$ ]. W poniższej tabeli dla jasności analizy podajemy zarówno wymagania morfoskładniowe, jak i semantyczne dla wyszczególnionych wybranych czasowników, ale tylko w tym zakresie, który głównie odnosi się do omawianego przekształcenia składniowego: $\mathrm{NP}^{1}{ }_{\text {Nom }} \mathrm{V} \mathrm{NP}^{2}{ }_{\text {Acc }} \mathrm{XP}^{3}{ }_{\text {abl }}$ $\left(\right.$ PrepNP $_{z, \text { Gen })}{ }^{11} \rightarrow \mathrm{NP}^{1}{ }_{\text {Nom }}$ V NP $_{\text {Acc }}^{2} \operatorname{PrepNP}_{z, \text { Gen }}$.

"периферия" построен на ассоциации с периферийными падежами по Якобсону.) (...)" [Paduczewa 1998, 5].

„(...) w sytuacji [opisywanej przez dany czasownik - dop. PP] wyróżnia się plan pierwszy i plan peryferyjny (odpowiednio, mówi się o centralnych i peryferyjnych uczestnikach; odpowiadaja im centralne i peryferyjne komponenty interpretacji). (...) Odwołujemy się do pojęcia di a te zy wg Mielczuka i Chołodowicza [1970], lecz diatezę określamy nieco inaczej - jako zbiór uczestników sytuacji z ich komunikatywnymi rangami: Subiekt, Obiekt, Peryferia, Poza kadrem, o czym szczegółowo w: [Paduczewa 1997]. (Chodzi o to, że Subiekt i Obiekt, będąc kategoriami składniowymi, maja wszelako bezpośrednią wartość komunikatywną, natomiast termin „peryferia” tworzony jest na zasadzie asocjacji z peryferyjnymi przypadkami wg Jakobsona) (...)" [tłum. PP].

${ }_{11}$ Podana tu fraza ablatywna została użyta celowo, choć skupiamy się w niniejszym artykule jedynie na jej realizacji w formie konkretnej frazy przyimkowo-nominalnej, która jest: PrepNP ${ }_{z, G e n}^{3}$. Zdajemy sobie jednak sprawę $z$ możliwych innych użyć (zależnych od wymagań składniowo-semantycznych) danego cza- 


\begin{tabular}{|c|c|c|c|c|}
\hline $\begin{array}{l}\text { CZASO- } \\
\text {-WNIK }\end{array}$ & \begin{tabular}{|c|} 
PRZYKLAD \\
UŻYCIA \\
Z WALENTEGO \\
\end{tabular} & $\begin{array}{l}\text { TYPY } \\
\text { FRAZ }\end{array}$ & $\begin{array}{c}\text { ROLE SEMANTYCZNE } \\
\text { + PREFERENCJE } \\
\text { SELEKCYJNE }\end{array}$ & $\begin{array}{l}\text { RAMA } \\
\text { SEMAN- } \\
\text {-TYCZNA }\end{array}$ \\
\hline \multirow{5}{*}{$\begin{array}{l}\text { depilo- } \\
\text { wać } \\
\text { wyde- } \\
\text { pilować }\end{array}$} & wtosy & $\mathrm{NP}(\mathrm{str})^{12}$ & Theme ${ }^{\text {Goal: }}$ 'owłosienie' & \multirow{5}{*}{$\begin{array}{l}1 \\
\text { wspólna } \\
\text { rama }\end{array}$} \\
\hline & $\begin{array}{l}\text { z wrażliwych } \\
\text { miejsc }\end{array}$ & $\mathrm{XP}(\mathrm{abl})$ & Theme $e^{\text {Source: 'część ciała' }}$ & \\
\hline & $\begin{array}{l}\text { *inne w tej } \\
\text { pozycji: } \\
\text { (włosy) w nosie }\end{array}$ & XP (locat) & Theme Source: 'część ciała' & \\
\hline & uszka & $\mathrm{NP}(\mathrm{str})$ & 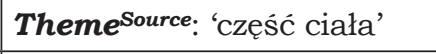 & \\
\hline & z włosków & PrepNP ${ }_{z, \text { Gen }}$ & Theme ${ }^{\text {Goal: }}$ 'owłosienie' & \\
\hline \multirow{6}{*}{$\begin{array}{l}\text { grabić } \\
\text { zgrabić }\end{array}$} & liście & NP(str) & $\begin{array}{l}\text { Theme Goal: 'pozostałość', } \\
\text { 'liść', 'siano' }\end{array}$ & \multirow{6}{*}{$\begin{array}{l}1 \\
\text { wspólna } \\
\text { rama }\end{array}$} \\
\hline & z trawnika & $\mathrm{XP}(\mathrm{abl})$ & $\begin{array}{l}\text { Themesource: 'alejka', 'pole', } \\
\text { 'trawnik' }\end{array}$ & \\
\hline & $\begin{array}{l}\text { *inne w tej } \\
\text { pozycji: } \\
\text { (liście) sprzed } \\
\text { domu }\end{array}$ & $\mathrm{XP}(\mathrm{abl})$ & $\begin{array}{l}\text { Theme Source: 'alejka', 'pole', } \\
\text { 'trawnik' }\end{array}$ & \\
\hline & $\begin{array}{l}\text { (liście) na } \\
\text { poboczach }\end{array}$ & XP (locat) & Location ${ }^{\text {Source: }}$ 'miejsce' & \\
\hline & trawnik & $\mathrm{NP}(\mathrm{str})$ & 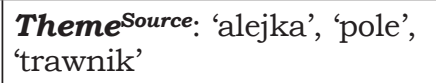 & \\
\hline & z liści & PrepNP $_{z, \text { Gen }}$ & $\begin{array}{l}\text { Theme } \\
\text { 'liśćc', 'siano': 'pozostałość', }\end{array}$ & \\
\hline \multirow{3}{*}{$\begin{array}{l}\text { powy- } \\
\text { cierać }\end{array}$} & smarki & $\mathrm{NP}(\mathrm{str})$ & $\begin{array}{l}\text { Theme Goal: 'substancja', } \\
\text { 'wilgoć', 'pot', 'krew', 'brud', } \\
\text { 'kurz' }\end{array}$ & \multirow{3}{*}{$\begin{array}{l}1 \\
\text { wspólna } \\
\text { rama }\end{array}$} \\
\hline & $z$ podtogi & $\mathrm{XP}(\mathrm{abl})$ & $\begin{array}{l}\text { Theme Source: 'obiekt', 'część } \\
\text { ciała', 'istota' / } \\
\text { Location: 'otoczenie' }\end{array}$ & \\
\hline & $\begin{array}{l}\text { *inne w tej } \\
\text { pozycji: } \\
\text { (kurz) spod } \\
\text { telewizora }\end{array}$ & $\mathrm{XP}(\mathrm{abl})$ & $\begin{array}{l}\text { Themesource: 'obiekt', 'część } \\
\text { ciała', 'istota' }\end{array}$ & \\
\hline
\end{tabular}

sownika typu: wytrzeć [coś] spod stołu, wytrzepać [coś] zza kołnierza, sprzątnąc [coś] spomiędzy szafek itp.

12 Jak wyjaśniaja twórcy słownika Walenty, skrót str odpowiada pojęciu przypadka strukturalnego - oznaczającego „przypadek, którego wartość jest zależna od kontekstu składniowego. Jego wystapienie na pozycji podmiotu oznacza domyślny rzeczownik, na pozostałych pozycjach oznacza domyślny biernik" [Hajnicz, Nitoń 2017, 11; zob. też Przepiórkowski i in. 2014, 163]. 


\begin{tabular}{|c|c|c|c|c|}
\hline $\begin{array}{l}\text { CZASO- } \\
\text {-WNIK }\end{array}$ & $\begin{array}{c}\text { PRZYKLAD } \\
\text { UŻYCIA } \\
\text { Z WALENTEGO }\end{array}$ & $\begin{array}{l}\text { TYPY } \\
\text { FRAZ }\end{array}$ & $\begin{array}{c}\text { ROLE SEMANTYCZNE } \\
\text { + PREFERENCJE } \\
\text { SELEKCYJNE }\end{array}$ & $\begin{array}{l}\text { RAMA } \\
\text { SEMAN- } \\
\text {-TYCZNA }\end{array}$ \\
\hline & $\begin{array}{l}\text { (kurz) na } \\
\text { meblach }\end{array}$ & XP(locat) & Location: 'otoczenie' & \\
\hline & pędzle & $\mathrm{NP}($ str) & $\begin{array}{l}\text { Theme } \text { Source: 'obiekt', 'część } \text { ciała', 'istota' }\end{array}$ & \\
\hline & $z$ farb & PrepNP $_{z, \text { Gen }}$ & $\begin{array}{l}\text { Theme Goal: 'substancja', } \\
\text { 'wilgoć', 'pot', 'krew', 'brud', } \\
\text { 'kurz' }\end{array}$ & \\
\hline \multirow{4}{*}{$\begin{array}{l}\text { sprza- } \\
\text { tać } \\
\text { sprzat- } \\
\text { nąć }\end{array}$} & towar & $\mathrm{NP}(\mathrm{str})$ & Theme 'rzecz' & \multirow{2}{*}{$\begin{array}{l}1 . \\
\text { odrębna } \\
\text { rama }\end{array}$} \\
\hline & z pótki & $\mathrm{XP}(\mathrm{abl})$ & Location ${ }^{\text {Source: }}$ 'otoczenie' & \\
\hline & jezdnie & $\mathrm{NP}($ str) & $\begin{array}{l}\text { Themesource: 'miejsce', } \\
\text { 'mebel', 'pomieszczenie', } \\
\text { 'powierzchnia' }\end{array}$ & \multirow{2}{*}{$\begin{array}{l}2 . \\
\text { odrębna } \\
\text { rama }\end{array}$} \\
\hline & $\begin{array}{l}z \text { resztek } \\
\text { rozbitych aut }\end{array}$ & PrepNP $_{z, \text { Gen }}$ & $\begin{array}{l}\text { Theme } \text { 'Goal: 'zanieczyszczenie', }^{\text {'nieporządek', 'pozostałość' }} \\
\end{array}$ & \\
\hline \multirow{6}{*}{$\begin{array}{l}\text { wycie- } \\
\text { rać } \\
\text { wytrzeć }\end{array}$} & resztki & $\mathrm{NP}($ str) & $\begin{array}{l}\text { Theme Goal: 'wilgoć', 'pot', } \\
\text { 'krew', 'brud', 'kurz' }\end{array}$ & \multirow{6}{*}{$\begin{array}{l}1 \\
\text { wspólna } \\
\text { rama }\end{array}$} \\
\hline & z ust & $\mathrm{XP}(\mathrm{abl})$ & $\begin{array}{l}\text { Theme Source: 'istota' ', 'część } \\
\text { ciała', obiekt' / } \\
\text { Location: 'otoczenie' }\end{array}$ & \\
\hline & $\begin{array}{l}\text { *inne w tej } \\
\text { pozycji: } \\
\text { (wilgoc) } \\
\text { spomiędzy ud }\end{array}$ & $\mathrm{XP}(\mathrm{abl})$ & $\begin{array}{l}\text { Theme Source: 'istota' ', 'część } \\
\text { ciała', obiekt' / } \\
\text { Location: 'otoczenie' }\end{array}$ & \\
\hline & $\begin{array}{l}\text { (pot) pod } \\
\text { pachami }\end{array}$ & XP(locat) & Location: 'otoczenie' & \\
\hline & usta & $\mathrm{NP}(\mathrm{str})$ & $\begin{array}{l}\text { Theme Source: 'istota' ', 'część } \\
\text { ciała', obiekt' }\end{array}$ & \\
\hline & z soli & PrepNP $_{z, \text { Gen }}$ & $\begin{array}{l}\text { Theme Goal: 'wilgoć', 'pot', } \\
\text { 'krew', 'brud', 'kurz' }\end{array}$ & \\
\hline \multirow{5}{*}{$\begin{array}{l}\text { wytrze- } \\
\text { pywać } \\
\text { wytrze- } \\
\text { pać }\end{array}$} & śnieg & $\mathrm{NP}(\mathrm{str})$ & $\begin{array}{l}\text { Theme } \\
\text { 'soal: 'śnieg', } \\
\end{array}$ & \multirow{5}{*}{$\begin{array}{l}1 \\
\text { wspólna } \\
\text { rama }\end{array}$} \\
\hline & z rękawów & $\mathrm{XP}(\mathrm{abl})$ & Location ${ }^{\text {Source: }}$ 'położenie' & \\
\hline & $\begin{array}{l}\text { *inne w tej } \\
\text { pozycji: } \\
\text { (śnieg) zza } \\
\text { kołnierza }\end{array}$ & $\mathrm{XP}(\mathrm{abl})$ & Location ${ }^{\text {Source: }}$ 'położenie' & \\
\hline & worek & $\mathrm{NP}(\mathrm{str})$ & 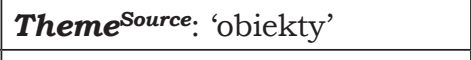 & \\
\hline & z mąki & PrepNP $_{z, \text { Gen }}$ & $\begin{array}{l}\text { Theme }{ }^{\text {Goal}:} \text { :'śnieg', } \\
\text { 'substancja', 'obiekt' }\end{array}$ & \\
\hline
\end{tabular}


Jak wynika $z$ powyższego, w Walentym nie do końca konsekwentnie opisuje się na poziomie semantycznym omawiane regularne przekształcenie składniowe ${ }^{13}$ (być może wynika to głównie $z$ tego, że wiele jednostek nie ma jeszcze statusu haseł ostatecznie zatwierdzonych przez redaktora). W wypadku bowiem realizacji typu grabić / zgrabić liście (locatum argument) $z$ trawnika (location argument) w zdecydowanej większości przykładów locatum argument ma faktycznie przyporządkowana jedna role semantyczna Theme ${ }^{\text {Goal }}{ }^{14}$ (ewentualnie Theme ${ }^{15}$ jak w opisie czasowników sprzatać, sprzatnaç), z kolei location argument notowany jest już zarówno jako Theme ${ }^{\text {Source }}$ bądź Location Source, 16 ewentualnie Location $^{17}$ i nie wpływa na to fakt, czy na poziomie zdania argument ten realizowany jest tylko przez frazę ablatywna, czy także przez frazę lokatywną. Konsekwencję widać natomiast w opisie semantycznym konstrukcji typu grabić / zgrabić trawnik (location argument) z liści (locatum argument), gdyż zawsze wyróżniane sa tu role Theme $e^{\text {Source (location argument) }}$ oraz Theme Goal (locatum argument). Zaznaczmy jednak, że w prezentacji danej ramy semantycznej ${ }^{18}$ hierarchia tych argumentów nie zmienia

13 Pomijam tu problem niepodawania przykładów, które ilustrowałyby w pełni omawianą alternację lokatywną. W Walentym odnaleźć można bowiem wiele takich opisów czasowników, dla których zjawisko to zachodzi, a odnotowany jest tylko jeden wariant przekształcenia, zob. np. czyścić, skrobać, skubać, trzepać, plewić itp.

14 „Zupełnie nową koncepcją wprowadzoną w Walentym jest dwupoziomowa reprezentacja ról semantycznych, polegająca na możliwości opatrywania ról semantycznych atrybutami. (...) Rolę główną opatrujemy atrybutami Source, Goal wówczas, gdy oba argumenty pełnia taką samą rolę w zdaniu, ale sytuacja wskazuje szeroko rozumiany kierunek wykonywanej czynności czy procesu. Source to początek, źródło procesów, czynności, a Goal to cel, do którego się dąży lub etap końcowy procesu, czynności" [Hajnicz, Nitoń 2017, 33; zob. też Hajnicz i in. 2016].

15 Theme należy do grupy towarzyszacej, zawierającej „uczestników sytuacji, którzy podlegają (w sposób bierny) sytuacji lub ją charakteryzuja, oraz takich, którzy sa niezbędni do zajścia sytuacji, jednak nie inicjuja jej samodzielnie. (...) Theme podlega jakiemuś procesowi czy działaniu lub znajduje się w jakimś stanie; często podlega zmianie w wyniku zajścia sytuacji (...)" [Hajnicz, Nitoń 2017, 31].

16 „Location ${ }^{\text {Source }}$ realizowana składniowo przez xp(abl) oraz Location ${ }^{\text {Goal }}$ realizowana składniowo przez xp(adl) różnia się semantycznie od pozbawionej atrybutów Location, realizowanej składniowo przez xp(locat) (...)" [Hajnicz, Nitoń 2017, 33].

17 Rola Location określa miejsce, w którym wydarza się dana sytuacja bądź też miejsce, „skąd lub dokąd zmierza jej Initiator czy też Theme; zazwyczaj w Walentym będzie realizowana składniowo jako xp(locat), xp(abl), xp(adl) (...)" [Hajnicz, Nitoń 2017, 32].

18 Rama semantyczna w ujęciu Ch. Fillmore'a to system pojęć, które połaczone sa ze sobą tak, że aby móc zrozumieć jedno $z$ nich, należy odnieść się do całej struktury, w której dane pojęcie się pojawia. Użycie w tekście konkretnej jednostki leksykalnej polega na przywołaniu ramy, do której ta jednostka jest przypisana, czyli przywołaniu określonej struktury pojęć - pewnej prototypowej 
się (jest to zwykle jedna rama, co należy interpretować jako jedno znaczenie) w zależności od danego wariantu przekształcenia składniowego w obrębie alternacji lokatywnej. Diatezę widać jedynie na poziomie opisu morfoskładniowego (zob. np. hasło zgrabic). Inaczej jest np. w hasłach sprzątać, sprzatnać, w których odrębnym schematom składniowym i ich realizacjom tekstowym przyporządkowano odrębne ramy semantyczne (zob. tabela powyżej). Najistotniejsze jest jednak to, że Walenty (w przeciwieństwie na przykład do SSGCP) odnotowuje omawiane regularne zjawisko językowe, choć nie zawsze czyni to w pełni konsekwentnie. Byłoby dobrze, gdyby autorzy haseł trzymali się jednak stałego zestawu ról semantycznych, odpowiadających tu wymiennemu układowi argumentów: locatum argument i location argument.

\section{ALTERNACJA LOKATYWNA W WYBRANYCH OPRACOWANIACH ANGIELSKOJEZYCZNYCH}

Bliskie opisowi alternacji lokatywnej w Walentym jest podejście prezentowane we FrameNecie - bazie ram semantycznych dla czasowników angielskich i innych wyrażeń denotujących sytuacje [zob. http:// framenet.icsi.berkeley.edu, Baker, Fillmore, Cronin 2003; też Fillmore 1982]. Odnajdujemy tam interesująca nas ramę Removing ( $\mathrm{z}$ ang. 'usuwanie'), która definiowana jest tak:

An Agent causes a Theme to move away from a location, the Source. The Source is profiled by the words in this frame, just as the Goal is profiled in the Placing frame [zob. FrameNet Data, https://framenet.icsi.berkeley.edu/fndrupal/index.php?q=frameIndex - 30.01.2019]. ${ }^{19}$

Co ważne, $z$ ramą ta powiazane sa odpowiednie znaczenia czasowników takich jak: clear, drain, empty, evacuate, flush, które pojawiaja się także w pracy B. Levin jako leksemy realizujące alternację lokatywną [zob. Levin 1993, 52-53]. I faktycznie w opisie ramy Removing odnotowano możliwość zajścia tej alternacji w wyniku wzajemnej zamiany pozycji poszczególnych aktantów, którym przypisano role: Theme 'obiekt, który zmienia swoją lokalizację, przemieszczający się obiekt fizyczny' oraz Source 'miejsce poczatkowe Theme - obiektu przed zmiana jego lokalizacji':

sytuacji i jej stałych elementów [zob. Fillmore 1982, też: Zawisławska 2010; Linde-Usiekniewicz 2010].

19 „Agent powoduje, że Theme jest usuwany z jakiegoś miejsca - Source. Source jest profilowany przez wyrazy w tej ramie, tak jak Goal jest profilowany w ramie - umieszczanie" [tłum. PP]. 
A few of the words in this frame participate in an alternation between a Theme object and a Source object. The waiter CLEARED the dishes from the table. The waiter CLEARED the table of dishes. (...) The gardener EMPTIED the soil from the bucket. The gardenerEMPTIED the bucket of soil [FrameNet Data, 30.01.2019]. ${ }^{20}$

W podobny sposób notuje się analizowane zjawisko w języku angielskim w obrębie ramy Emptying ( $z$ ang. 'opróżnianie'):

These are words relating to emptying containers and clearing areas of some substance or items. The area or container can appear as the direct object with all these verbs, and is designated Source because it is the source of motion of the Theme (...) [FrameNet Data, https://framenet.icsi.berkeley.edu/fndrupal/ index.php?q=frameIndex, 30.01.2019].21

Powyższa ramę ilustruje się w bazie m.in. następującymi użyciami: Pat CLEARED the table of dishes. Pat CLEARED the table ${ }^{22}$ [FrameNet Data]. Takie ujęcie wskazywałoby zatem na fakt, że alternujace ze soba konstrukcje sa tu traktowane nie jako przejaw odrębnych znaczeń danej jednostki leksykalnej, ale jako dwie możliwości syntaktycznego wyrażenia tej samej treści dotyczacej jednej sytuacji.

B. Levin w semantyce zdań realizujących omawianą alternację lokatywna dostrzega jednak pewną zmianę znaczeniowa, o której tak pisał już Stephen R. Anderson, analizując strukturę głęboką zdania w kontekście przekształceń omawianego typu i argumentując przeciw czysto syntaktycznemu spojrzeniu na tego typu użycia:

Since the property with which we dealing seems to be a matter of whether the whole of something is affected by the action described by the sentence, or just a part of it is affected, let us coin the terms holistic interpretation and partitive to denote the difference [Anderson 1971, 389]. ${ }^{23}$

Badaczka dodaje, że przeprowadzenie precyzyjnej charakterystyki całościowego / częściowego ujęcia sytuacji nazywanej przez dany czasownik sprawia wiele trudności, zwłaszcza że samo określenie - oddzia-

20 „Niektóre wyrazy w tej ramie podlegają alternacji, która zachodzi pomiędzy obiektem - Theme a obiektem - Source. Kelner posprzatał naczynia ze stołu. Kelner posprzątał stół z naczyń. Ogrodnik opróżnił ziemię z wiadra. Ogrodnik opróżnił wiadro z ziemi" [tłum. PP].

21 „Sa to słowa związane $z$ opróżnianiem pojemników i czyszczeniem obszarów $z$ niektórych substancji lub rzeczy. Wyraz nazywający jakiś obszar lub pojemnik może wystapić w funkcji dopełnienia bliższego w zdaniu zbudowanym za pomoca wszystkich tych czasowników i jest on oznaczony jako Source, ponieważ jest poczatkiem przemieszczania się Theme" [tłum. PP].

22 „Pat posprzatał stół z naczyń. Pat posprzątał stól” [tłum. PP].

23 „Ponieważ właściwość, z która mamy do czynienia, wydaje się kwestią tego, czy na całość czegoś wpływa działanie opisane przez zdanie, czy tylko wpływa to na jego część, aby zaznaczyć różnicę, wprowadźmy terminy całościowa interpretacja i częściowa interpretacja" [tłum. PP]. 
ływanie całościowe / częściowe ( $\mathrm{z}$ ang. holistic / partitive effect) nie jest, jej zdaniem, wystarczajacco celne [Levin 1993, 50]. Tak więc, mechanizm alternacji lokatywnej sprawia, że daną sytuację nazywana przez określony czasownik ujmuje się $z$ dwu różnych perspektyw: albo 1 . wybiórczo, zwracając uwagę na detal (tu: 'drobna materię znajdującą się na jakiejś powierzchni') będący obiektem czynności na jakimś tle, które jest jednocześnie miejscem początkowym przemieszczania, usuwania tej drobnej materii; albo 2. całościowo, ukazując całe tło czynności - plan ogólny będący pełnym obrazem i miejscem akcji (tu: obiekt, otoczenie, $z$ powierzchni którego coś jest usuwane). $Z$ pierwszą perspektywą mamy do czynienia w konstrukcjach, w których w funkcji dopełnienia bliższego pojawia się fraza nominalna (tu: kurz, śmieci, włosy, pot, okruszki, liście itp.) wypełniajaca argumentowa pozycje obiektu - Theme (locatum argument), zob. grabić liście $z$ trawnika, zamiatać śmieci $z$ ulicy, golić włosy $z$ nóg itp. oraz grabić liście, zamiatać śmieci, golić włosy itp. (jako efekt alternacji zaniku). $Z$ kolei druga perspektywa widoczna jest w konstrukcjach, w których funkcję dopełnienia bliższego przejmuje fraza nominalna (tu: półka, podłoga, ulica, nogi, twarz, trawnik itp.) pełniąca rolę semantyczna Source 'miejsce, $z$ którego coś jest przemieszczane i które jest zarazem obiektem czynności' (location argument), zob. grabić trawnik z liści, zamiatać ulice ze śmieci, golić nogi $z$ włosów itp. (jako efekt alternacji krzyżowej) oraz grabić trawnik, zamiatać ulice, golić włosy itp. (jako efekt alternacji zaniku lub przesunięcia). Stosując terminologię kognitywna (pozwalająca uniknąć nieprecyzyjnych określeń oddziaływania częściowego / całościowego), możemy mówić tu o zawężaniu i rozszerzaniu perspektywy - ramy oglądu, a ściślej, jak tłumaczy to Adam Głaz omawiający teorię oglądu Roberta McLaury'ego, o „mentalnym przybliżaniu lub oddalaniu się od konceptualizowanego obiektu” [Głaz 2006, 167].

Proces mentalnego przybliżania i oddalania zachodzi analogicznie do (...) przestrzennego zawężenia pola, jak ma to miejsce w zdaniu Gazeta jest w salonie na stole. Aby zlokalizować gazetę, trzeba najpierw znaleźć salon w mieszkaniu, w salonie zlokalizować stół i wreszcie gazetę „względem” stołu. W codziennych działaniach stale przybliżamy się [do obiektów] lub oddalamy mentalnie [od nich] (...), skupiamy się na czymś bądź nasza uwaga jest rozpraszana (...) [McLaury 1995, 243-244, za: Głaz 2006, 168].

To, w jakim sposób postrzegamy scenę, można również opisać, używając $z$ teorii Ronalda W. Langackera takich pojęć jak obrazowanie, ogniskowanie, figura, tło [zob. Langacker 1987; 2009, 85 i in.]. Ogniskowanie, jako jeden $z$ aspektów obrazowania, wiaże się bowiem $z$ możliwością wyboru i różnego rozkładu treści pojęciowej, a dzięki temu uwydatnieniu jakichś elementów znaczenia przy równoczesnym osłabieniu innych [zob. też Winiarska, Załazińska 2018]. Uwzględnianie zmiany perspektywy oglądu oraz spojrzenie ukierunkowane na semantykę omawianych przekształceń wyraźnie widać w pracach rosyjskojęzycznych, w których nie pisze się o alternacjach, lecz o polisemii regularnej. 


\section{ALTERNACJA LOKATYWNA W WYBRANYCH OPRACOWANIACH ROSYJSKOJĘZYCZNYCH}

Podane tu przykłady czasowników realizujących alternację lokatywną pojawiają się $\mathrm{w}$ kontekście rozważań nad polisemią regularna ${ }^{24} \mathrm{w}$ ujęciu Jurija D. Apresjana, a konkretnie przy omówieniu jednego $z$ jej typów, mianowicie - 'obrabiać w określony sposób' $\rightarrow$ 'usuwać w ten sposób' [Apresjan 1971; 1980, 266]. Zdaniem badacza pary przesunięć semantycznych, takie jak: wytrzepać (worek $\rightarrow$ makę $z$ worka), oberwać (krzaki $\rightarrow$ bez z krzaków), obmieść (sufit $\rightarrow$ pajęczynę $z$ sufitu) itp. sprowadzaja się do różnicy w kierunkach postrzegania danej sytuacji, czyli w układzie aktantów bądź innymi słowy: pary te różnią się „nie zbiorem bardziej elementarnych predykatów, które sa jednakowe, lecz tylko ich sposobem organizacji" [Apresjan 1980, 264]. Wprawdzie badacz ilustruje ten rodzaj polisemii użyciami takimi jak: skrobać (rybę- łuski), strzyc (owce - wetnę), golić (nogi - włosy), wyczesać (głowe - łupież), to w wyjaśnianiu mechanizmu przesunięcia odwołuje się do kierunku przekształcenia implikacyjnego typu: zamiatać śmieci $z$ podłogi > zamiatać podłoge [zob. Apresjan 1980, 262-271], które $z$ kolei wprost odpowiada kierunkowi zmiany w opisywanej tu alternacji lokatywnej. Co ważne, zjawisko polisemii regularnej, ${ }^{25} \mathrm{w}$ tym systematycznej wieloznaczności czasownika, szczegółowo opisuje się i uwzględnia w najnowszym słowniku pod redakсјає Apresjana pt. Активный словарь русского языка [2014, t. 1, 2. 2; 2017, t. 3, zob. też Apresjan (red.) 2010, 337 i in.; zob. np. hasło czasownikowe бpums 'golić' - Apresjan (red.) 2014, 354]. W niniejszym artykule szczegółowo przedstawimy jednak inna koncepcję opisu leksykograficznego polisemii regularnej w języku rosyjskim, chodzi mianowicie o metodę interpretacji semantycznej zaproponowana w bazie czasowników Leksykograf [zob. opis projektu Kustowa, Paduczewa 1994; Kustowa, Paduczewa, Rozina i in. 2009-2010; http://lexicograph.ruslang.ru /04DataBase.htm]. ${ }^{26}$

Nadmieńmy tylko, że interpretacja ta (określana tu $\mathrm{z}$ ros. толкование 'objaśnianie, interpretacja') jest jednym $z$ elementów mikrostruktury słownika ${ }^{27}$ i rozumie się ja jako rodzaj scenariusza opisujaccego zdarze-

24 Badacz tak ja definiuje: „wieloznaczność wyrazu A o znaczeniach $a_{i}$ i a nazywamy regularna, jeżeli w danym języku istnieje co najmniej jeden wyraz $\mathrm{B}$ o znaczenia $b_{i} i b_{j}$, które pod względem semantycznym różnią się od siebie tak samo, jak $a_{i}$ od $a_{j}$, i jeżeli $a_{i}-b_{i}, a_{j}-b_{j}$ nie sa synonimami" [Apresjan 1980, 243].

$25 \mathrm{Na}$ temat opisu polisemii regularnej czasownika w polskich słownikach ogólnodefinicyjnych zob. Pałka 2014.

26 Metoda ta wyrasta $z$ tradycji podobnych koncepcji opisu znaczenia - zob. m.in. Apresjan 1974; Bogusławski 1978; Fillmore 1968; Jackendoff 1990; Mielczuk 1989; Wierzbicka 1980.

27 1. wyraz hasłowy $z$ cytatami, 2. klasa tematyczna, 3. klasa taksonomiczna (T-kategoria), 4. charakterystyka aspektowa, 5. struktura argumentów: 
nie [Paduczewa 2009, 9] i mającego postać powtarzalnego schematu podzielonego na kolejne kroki reprezentujace ciąg przyczynowo-skutkowy (opisane symbolami K1, K2, .., K10). Ów schemat Galina Kustowa i Jelena Paduczewa nazywaja formatem interpretacji (ros. фoopмam толкования), wyjaśniajac, iż założeniem formatowania jest podział interpretacji na syntaktycznie niezależne semantyczne komponenty przedstawione $\mathrm{w}$ formie predykatywnej. ${ }^{28} \mathrm{Na}$ przykład czasownik местu 'zamiatać', zaliczany do kategorii taksonomicznej (T-kategorii): ${ }^{29}$ czynności ( $\mathrm{z}$ ros. деятельность), ${ }^{30} \mathrm{w}$ znaczeniu 'usuwać w określony sposób' - 1.1. местиопuлкu ${ }^{31}$ (zamiatać opiłki / trociny) ma następująca interpretację:

5a. charakterystyka syntaktyczna, 5b. charakterystyka semantyczna, 5c. ranga komunikatywna, 5d. przynależność do klasy taksonomicznej, 6. znaczenia derywowane [zob. Paduczewa 1994, 2009-2010].

${ }^{28}$ Każdy komponent opisuje odrębny parametr sytuacji typu: stan wyjściowy, nowy stan, działanie, sposób działania, kauzacja, kauzator, proces, rezultat itd. Jeśli danego parametru nie ma w semantyce danego leksemu, w prezentacji jest on pomijany, ale liczba kroków (K) pozostaje taka sama. Ponadto to, za pomoca jakich parametrów dany czasownik jest opisany, ustala się $z$ góry ze względu na to, do jakiej T-kategorii on należy [Kustowa, Paduczewa 1994, 96-97, zob. też Paduczewa 2008].

${ }^{29}$ Wyróżnia się: działania, czynności, zdarzenia, procesy, cechy, stany; zob. m.in. Paduczewa 1995; 1996; 2004.

30 Czynności ( $\mathrm{z}$ ros. деятельность) to grupa czasowników nazywających sytuacje dynamiczne, wielokrotne, nieterminatywne, majace jeden wspólny cel; określajacych ruch jednokrotny [zob. Paduczewa 1995; 2004].

${ }^{31} \mathrm{~W}$ bazie dla tego zn. 1.1. zgodnie ze schematem $\mathrm{NP}^{1}{ }_{\mathrm{Nom}} \mathrm{V} \mathrm{NP}{ }_{\text {Acc }}\left(\mathrm{NP}_{\text {Inst }}^{3}\right)$ $\left(\mathrm{XP}_{\text {abl }}^{4}\right)\left(\mathrm{XP}_{\text {adl }}\right)$ wyróżnia się $\mathrm{w}$ strukturze miejsce dla argumentów: agens - pacjens 'drobna materia'- instrument - miejsce 'punkt poczatkowy'- miejsce 'punkt końcowy', co przekłada się na następujące rangi komunikatywne uczestników: centrum - centrum - peryferie - peryferie - peryferie (np. Kуда ты метешь эти опилки?) [Gdzie zamiatasz te trociny? - thum. PP]. 


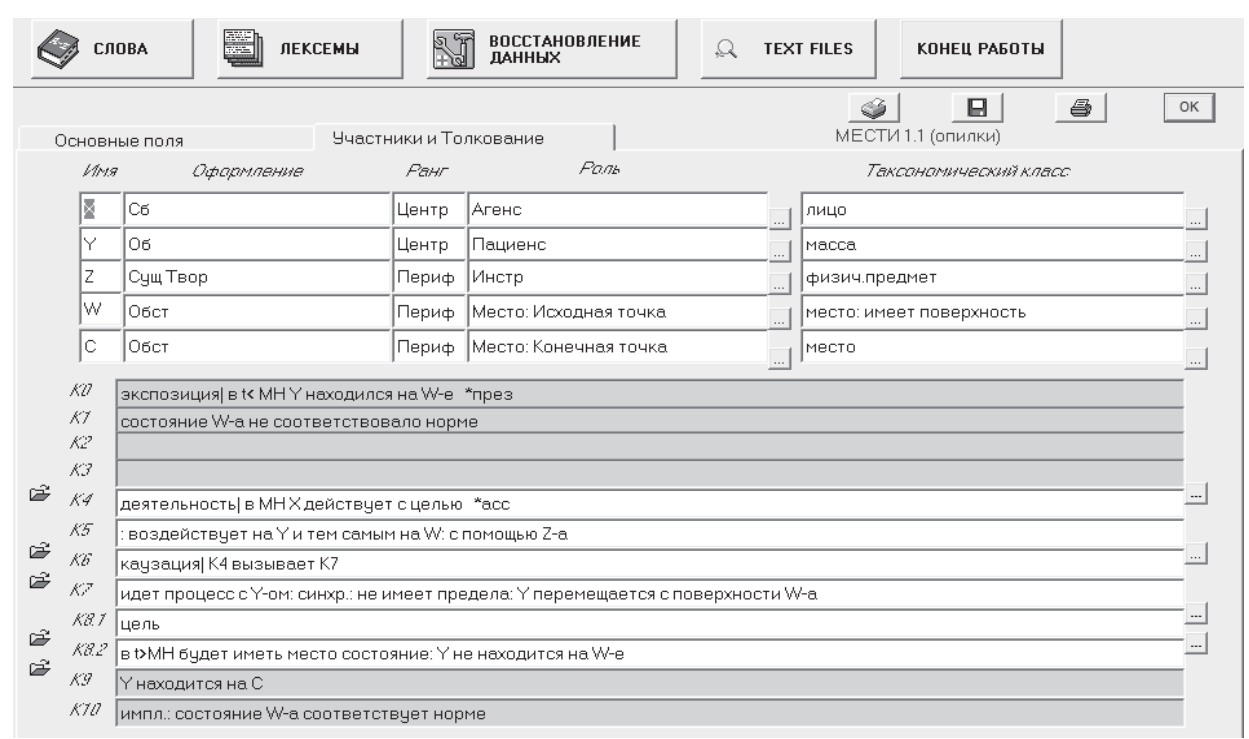

KO ekspozycja| w t $<\mathrm{MM}^{32}$ Y znajdował się na W

$\mathrm{K} 1 \mathrm{stan} \mathrm{W}$ nie odpowiadał normie

$\mathrm{K} 2$

K3

K4 czynność| w MM X działa w celu *acc

K5 oddziałuje na Y i tym samym na W: za pomoca $Z$

K6 kauzacja| K4 wywołuje K7

K7 zachodzi proces $z$ Y-em: synchronia: nie ma granicy: Y przemieszcza się

K8.1 cel

$\mathrm{z}$ powierzchni $\mathrm{W}$

K8.2 w t > MM będzie miał miejsce stan: Y nie znajduje się na $\mathrm{W}$

$\mathrm{K} 9$ Y znajduje się na $\mathrm{C}$

K10 implikacja: stan W odpowiada normie

$Z$ tak przedstawionej interpretacji semantycznej wynikaja nie tylko charakterystyczne parametry dla klasy czynności (podtypu: czasowniki przechodnie), takie jak: stan początkowy (K1), czynność (K4), sposób czynności (K5), kauzacja (K6), proces, w którym obiekt bierze udział (K7), celowość i rezultat czynności (K8), stan końcowy jako sąd presuponowany (K9). Co istotne, interpretacja ta wskazuje również na klasę tematyczna, do której należy dany leksem, tu klasę czasowników przemieszczania, a ściślej usuwania ( $z$ ros. перемешение: удаление), co odzwierciedla pierwsze znaczenie w systematycznym przesunięciu wg J.D. Apresjana typu 'usuwać w określony sposób' > 'obrabiać w ten sposób'. Jeśli zaś chodzi o regularne znaczenie drugie czasownika - 1.2. мести улиuу (za-

$32 \mathrm{MM}$ - moment mowy: „moment of speech (in the context of an utterance MS can be replaced by some other moment of reference)" [Paduczewa 2009, 8]. 
miatać ulicę), różnicę w interpretacji tego znaczenia stanowią następujacce komponenty (reszta jest taka jak w zn. 1.1):

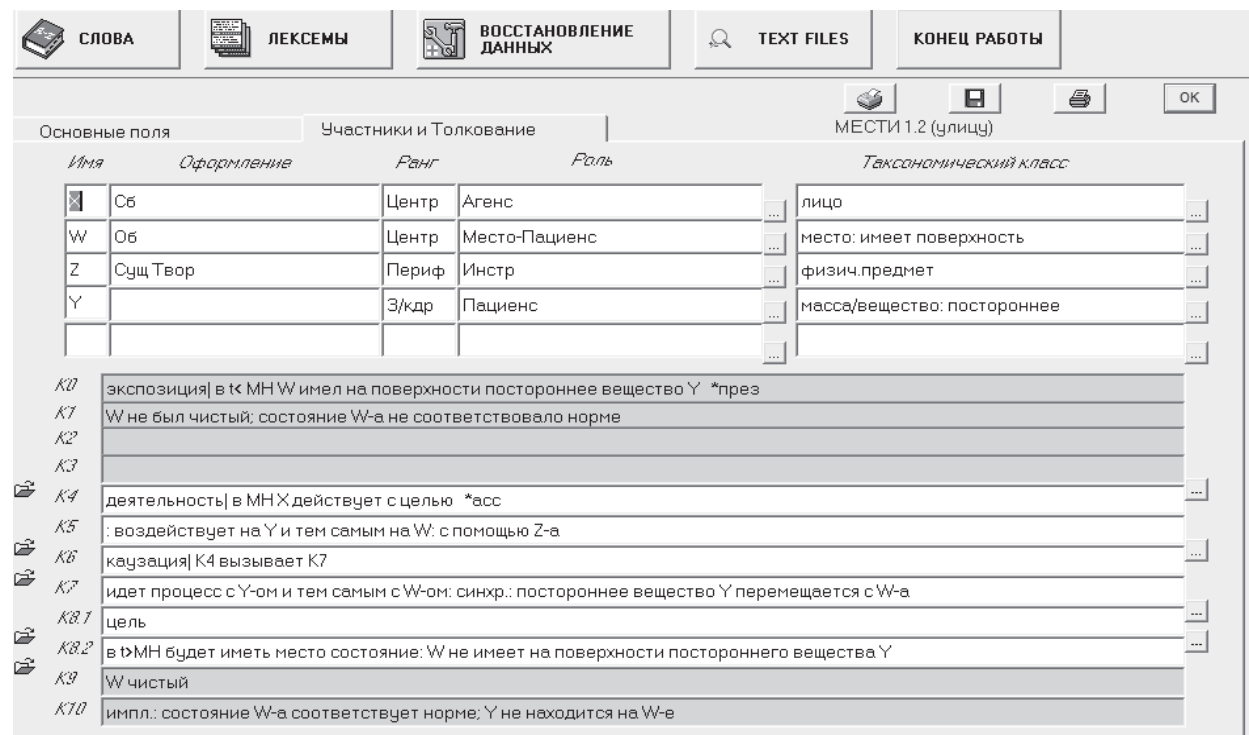

KO ekspozycja $\mid$ w $\mathrm{t}<\mathrm{MM}$ W miał na powierzchni obca substancję $\mathrm{Y}$

$\mathrm{K} 1 \quad \mathrm{~W}$ nie był czysty; stan $\mathrm{W}$ nie odpowiadał normie

$\mathrm{K} 2$

K3

K4 czynność| w MM X działa w celu

K5 oddziałuje na Y i tym samym na W: za pomoca $Z$

K6 kauzacja| K4 wywołuje K7

K7 zachodzi proces $z$ Y i tym samym $z$ W: synchronia: obca substancja Y przemieszcza się $z \mathrm{~W}$

K8.1 cel

K8.2 w t > MM będzie miał miejsce stan: W nie ma na powierzchni obcej substancji Y

K9 W czysty

K10 implikacja: stan W odpowiada normie; Y nie znajduje się na W

Tu z kolei interpretacja ujawnia, że choć nadal mamy do czynienia $z$ kategoria - czynności, to zmienia się klasa tematyczna czasowników, mianowicie znaczenie 1.2 . reprezentuje jednostki należące do pola semantycznego - zabieg, a ściślej oczyszczanie (z ros. обработка: очищение). Zmiana klasy tematycznej jest uznawana przez J.W. Paduczewa za jeden $z$ typów derywacji semantycznej [zob. Paduczewa 1998]. Omówiona zatem za słownikiem interpretacja czasownika ${ }^{33}$ мecmu uka-

33 Zob. też dyskusję z ujęciem Apresjana i Paduczewej m.in. w kontekście polisemii regularnej czasownika w artykule Romana Laskowskiego pt. Semantyka czasowników momentalnej zmiany a figura obserwatora [2014]. 
zuje różne sposoby ogniskowania i profilowania sytuacji oraz czynności, zależne od przyjętego punktu widzenia lub skupiania uwagi na jednym bądź drugim uczestniku sytuacji. W ramach jednej sceny w znaczeniu 1.1. uwypukla się aspekt usuwania, przemieszczania czegoś z jakiejś przestrzeni, przedstawiajac obraz $z$ dużą rozdzielczością i skupiając uwage na drobnych obiektach podlegających na jakimś tle czynności opisywanej przez dany czasownik. W komponencie ekspozycji (KO) stwierdza się bowiem stan (przed momentem mowy) obecności jakiejś obcej substancji na powierzchni czegoś, a następnie informuje się o rezultacie (K9) określonej czynności, w wyniku której ta substancja nie znajduje się już w tym miejscu (na tej powierzchni). Natomiast w opisie znaczenia 1.2 podkreśla się całościowa perspektywę, uwypukla się plan ogólny działania oraz aspekt obrabiania czegoś (przez usuwanie). W komponencie K0 przed momentem mowy odwraca się zatem kolejność postrzeganych elementów - jako pierwsze w polu widzenia pojawia się miejsce - obiekt określonej powierzchni, a potem dopiero obca materia, która się na nim znajduje. Skutkuje to dodatkowa informacja w stanie wyjściowym (K1): W (miejsce - obiekt) nie był czysty i innym rezultatem (K9): W jest czysty.

\section{PODSUMOWANIE}

Przedstawione rozważania stanowia zaledwie przyczynek do głębszych analiz omówionego tu zjawiska językowego. Co najważniejsze jednak, pokazuja one, iż, po pierwsze, wybrany do analizy rodzaj alternacji lokatywnej jest uwzględniany w mniejszym lub większym stopniu w specjalistycznych opracowaniach leksykograficznych i opisywany w nich pod kątem składniowym i/lub semantycznym. Po drugie, omawiane zjawisko ma charakter regularny i występuje zarówno w jezzyku polskim, angielskim, jak i rosyjskim. Po trzecie wreszcie, zaprezentowane omówienie udowadnia, że alternacja lokatywna może być też interpretowana jako jeden $z$ typów polisemii regularnej - 'usuwać w określony sposób' > 'obrabiać w ten sposób'. Dotyczy on takiego przesunięcia semantycznego, w którym w ramach jednej sytuacji ujawnia się inna perspektywa mówiącego, a ściślej inny sposób obrazowania. Dodatkowo tę zmianę znaczeniowa, wykorzystując na przykład metodologię kognitywną lub interpretacji semantycznej Paduczewej, można opisać w taki sposób, który pozwala ująć różnice w hierarchii aktantów, perspektywizacji i w profilowaniu czynności przez dany czasownik. Na koniec podkreślmy, że na temat alternacji i polisemii regularnej czasownika w języku polskim brakuje monografii - ujęć teoretyczno-metodologicznych, badań korpusowych oraz takich, które przedstawiaja konkretne rozwiąania w praktyce leksykograficznej. 


\section{Wykaz skrótów i symboli}

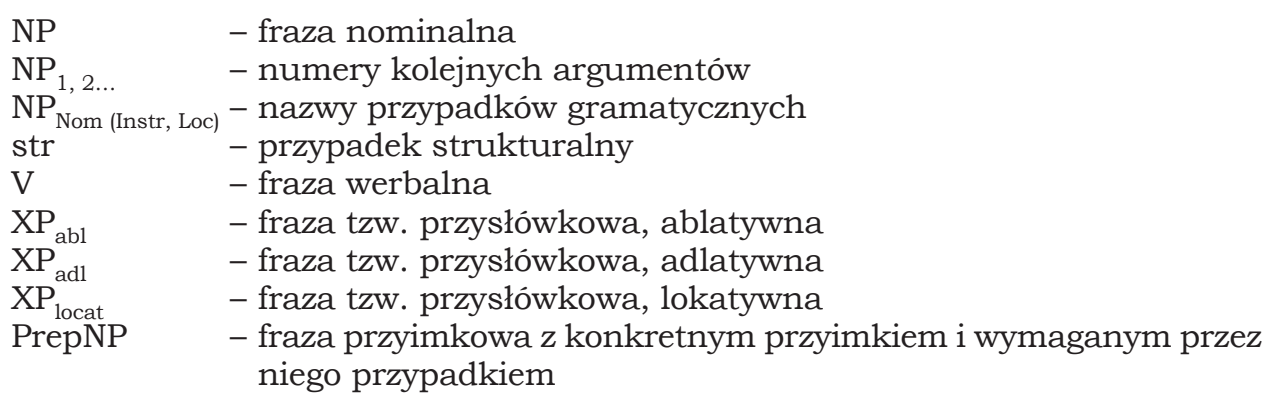

\section{Bibliografia}

S.R. Anderson, 1971, On the role of deep structure in semantic interpretation, „Foundations of Language” 7, s. 387-396.

J.D. Apresjan, 1971, [= Апресян Ю.Д.], О регулярной многозначности, „Известия АН СССР. Серия митературы и языка”, t. XXX, nr 6, s. 509-523.

J.D. Apresjan, 1974 [= Апресян Ю.Д.], Һексическая семантика: Синонимические средства языка, Москва.

J.D. Apresjan, 1980, Semantyka leksykalna. Synonimiczne środki języka, Wroclaw.

J.D. Apresjan (red.), 2010 [= Апресян Ю.Д.], Проспект активного словаря русского языка, Москва.

J.D. Apresjan (red.), 2014 [= Апресян Ю.Д.], Активный словарь русского языка, t. 1-2, Москва.

J.D. Apresjan (red.), 2017 [= Апресян Ю.Д.], Активный словарь русского языка, t. 3, Москва.

C.F. Baker, C.J. Fillmore, B. Cronin, 2003, The structure of the FrameNet database. „International Journal of Lexicography” 16(3), s. 281-296.

U. Brinkmann, 1997, The locative alternation in German, Amsterdam.

A. Bogusławski, 1978, Towards an operational Grammar, „Studia Semiotyczne” VIII, s. 29-90.

E.V. Clark, H.H. Clark, 1979, When nouns surface as verbs, „Language” 55, s. $767-811$.

C. Fillmore, 1968, The case for case [w:] E. Bach, R. T.Harms (red.), Universals in linguistic theory, New York, s. 1-88.

C. Fillmore, 1971, Some problems for case grammar [w] R.J. O'Brien (red.), Monograph series on languages and linguistics nr 24, Washington, s. 35-56.

C. Fillmore, 1977, Scenes-and-frames semantics [w:] A. Zampolli (red.), Linguistics structures processing, Amsterdam, s. 55-81.

C. Fillmore, 1982, Frame semantics [w]:Linguistic Society of Korea (red.), Linguistics in the morning calm, Seoul, s. 111-137 (online: http://brenocon.com/ Fillmore\%201982_2up.pdf., dostęp: 31.01.2019).

FrameNet: Baza ram semantycznych dla czasowników angielskich i innych wyrażeń denotujacych sytuacje. Pozyskano z http:/ / framenet.icsi.berkeley.edu 
A. Głaz, 2006, Kognitywizm na styku teorii - gramatyka kognitywna a teoria oglądu [w:] O. Sokołowska, D. Stanulewicz (red.), Językoznawstwo kognitywne III, Gdańsk, s. 154-181.

A.E. Goldberg, 1995, A construction grammar approach to argument structure, Chicago-London.

A.E. Goldberg, 2006, Constructions at work. The nature of generalization in language, Oxford.

E. Hajnicz, 2011, Automatyczne tworzenie semantycznych słowników walencyjnych, Warszawa.

E. Hajnicz, A. Andrzejczuk, T. Bartosiak, 2016, Semantic layer of the valence dictionary of Polish Walenty [w:] N. Calzolari, K. Choukri, T. Declerck, M. Grobelnik i in. (red.), Proceedings of the Tenth International Conference on Language Resources and Evaluation, LREC 2016, Portorož, s. 2625-2632.

E. Hajnicz, B. Nitoń, 2017, Instrukcja dostepu do słownika walencyjnego Walenty za pośrednictwem programu Slowal. CLARIN-PL (online: http:/ / clarin-pl.eu/wp-content/uploads/2017/05/instrukcja_uzytkownika_Walentego. pdf, dostęp: 31.01.2019).

R. Jackendoff, 1990, Semantic structure, Cambridge.

G.I. Kustowa, E.V. Paduczewa, 1994 [= Кустова Г.И., Падучева Е.В.], Словарь как лексическая база данных, „Вопросы языкознания” nr 4, s. 96-106.

G.I. Kustowa, E.V. Paduczewa, R.L. Rozina i in., 2009-2010 [= Кустова Г.И., Падучева Е.В., Розина Р.И], Проект Аексикограф (http:/ / lexicograph.ruslang.ru/04DataBase.htm, dostęp: 31.01.2019).

A. Laffut, 1998, The locative alternation: a constrative study of Dutch $v$ s. English, „Languages in Contrast” 1, s. 127-160.

R.W. Langacker, 1987, Foundations of Cognitive Grammar, t. 1: Theoretical prerequisites, Stanford.

R.W. Langacker, 2009, Gramatyka kognitywna, tłum. E. Tabakowska, Kraków.

R. Laskowski, 2014, Semantyka czasowników momentalnej zmiany a figura obserwatora, „Slavica Wratislaviensia” t. 159, s. 219-229.

B. Levin, 1993, English verb classes and alternations, Chicago.

B. Levin, M. Rappaport Hovav, 2005, Argument realization, Cambridge.

J. Linde-Usiekniewicz, 2010, Od przypadków głębokich do elementów ram we FrameNecie [w:] M. Zawisławska (red.), Rygorystyczna aplikacja metodologii kognitywno-interpretacyjnej, Warszawa, s. 17-52.

R.E. McLaury, 1995, Vantage theory [w:] J.R. Taylor, R.E. McLaury (red.), Language and the cognitive construal of world, Berlin-New York, s. 231-276.

I. Mielczuk, 1989 [= Mel'čuk I.], Semantic Primitives from the Viewpoint of the Meaning - Text Linguistic Theory, „Quaderni di semantica” nr 10(1), s. 65-102.

I. Mielczuk, A. Chołodowicz, 1970 [= Мельчук И.А., Холодович А.А.], К теории грамматического залога, „Народы Азии и Африки” nr 4, s. 111-124.

NKJP: A. Przepiórkowski, M. Bańko, R.L. Górski, B. Lewandowska-Tomaszczyk (red.), 2012, Narodowy Korpus Języka Polskiego. Warszawa, Warszawa (online: http://nkjp.pl/, dostęp: 31.01.2019).

E.V. Paduczewa, 1995 [= Paducheva E.V.], Taxonomic categories and semantics of aspectual opposition [w:] M. Bertinetto i in. (red.), Temporal reference, aspect and actionality. Semantic and syntactic perspectives, t. I, Torino, s. $71-90$. 
E.V. Paduczewa, 1996 [= Падучева Е.В.], Семантические исследования. Семантика времени и вида в русском языке. Семантика нарратива. М.: Языки славянской культуры, Москва.

E.V. Paduczewa, 1997, [= Падучева Е.В.], Семантические роли и проблема сохранения инварианта при лексической дериваиии, „Научно-техническая информация. Серия. 2. Информационные процессы и системы" nr 1, s. 18-30.

E.V. Paduczewa, 1998 [= Падучева Е.В.], Парадигма регулярной многозначности глаголов звука, „Вопросы языкознания” nr 5, s. 3-23.

E.V. Paduczewa, 2004 [= Падучева Е.В.], Динамические модели в семантике лексики. М.: Языки славянской культуры, Москва.

E.V. Paduczewa, 2008 [= Paducheva E.B.], Verb taxonomy and decompositional semantics od lexicon, L.A. (prezentacja, http://lexicograph.ruslang.ru /03MembersPadu.htm, dostęp: 31.01.2019).

E.V. Paduczewa, 2009 [= Paducheva E.B.], Event structure in Russian: semantic roles, aspect, causation, „The Prague Bulletin of Mathematical Linguistics” nr 92, s. 5-19.

P. Pałka, 2014, Polisemia regularna czasownika $w$ słownikach ogólnych języka polskiego, „Poradnik Językowy” z. 6 (715), s. 17-36.

A. Przepiórkowski, F. Skwarski, E. Hajnicz, A. Patejuk, M. Świdziński, M. Woliński, 2014, Modelowanie własności składniowych czasowników $w$ nowym słowniku walencyjnym języka polskiego, „Polonica” XXXIII, s. 159-178.

SSGCP: K. Polański (red.), 1980-1992, Słownik syntaktyczno-generatywny czasowników polskich, t. 1-5, Wrocław.

Walenty: Słownik walencyjny języka polskiego, IJP PAN (online: http:/ /walenty. ipipan.waw.pl/, dostęp: 31.01.2019).

A. Wierzbicka, 1980, Lingua mentalis, Sydney.

J. Winiarska, A. Załazińska, 2018, Multimodalność komunikacji w perspektywie kognitywizmu [w:] J. Winiarska, A. Załazińska (red.), Multimodalność komunikacji, Kraków, s. 7-18.

M. Zawisławska, 2010, Ramy interpretacyjne jako narzędzie opisu znaczenia [w:] M. Zawisławska (red.), Rygorystyczna aplikacja metodologii kognitywno-interpretacyjnej, Warszawa, s. 53-73.

P. Żmigrodzki, 2005, Wprowadzenie do leksykografii polskiej, Katowice. 


\section{Locative alternation in selected lexical databases}

\section{Summary}

The object of interest in this paper is verbs describing situations where substances or objects are being removed from a surface. Such verbs are characterised by being subject to locative alternation, which could be exemplified by constructions such as: Dozorca zamiata śmieci $z$ ulicy. $\rightarrow$ Dozorca zamiata ulice (ze smieci) (The caretaker is sweeping litter from the street. $\rightarrow$ The caretaker is sweeping the street (to remove litter)). The phenomenon of alternation consists in regular variantivity in the syntactic manifestation of verb arguments, whereas locative alternation, according to Beth Levin, concerns at least two manners of expressing arguments assuming the following properties: 1. 'an object changing its location' (locatum argument), and 2. 'a location' (location argument) in a sentence (Levin 1993: 50). The principal objective of the paper is to discuss whether and how locative alternation is taken into account and described in selected Polish-, English-, and Russian-language specialist lexicographic publications, such as: the Valence Dictionary (Walenty), FrameNet, and Leksykograf (Lexicographer), a base of Russian verbs. The analysis is also aimed to answer the question if the alternating syntactic structures reveal any change in the communicated content and, more specifically, in the manner of illustrating a given situation.

Keywords: verb - locative alternation - regular polysemy - semantics - syntax - lexicography. 